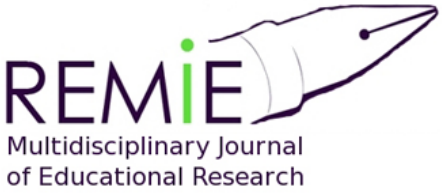

Multidisciplinary Journal

of Educational Research
Hipatia Press

www.hipatiapress.com

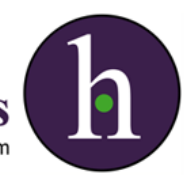

Instructions for authors, subscriptions and further details:

http://remie.hipatiapress.com

\title{
A Comparison of Assessment Beliefs of Science and Education Lecturers in a University
}

Mark S. Davies ${ }^{1}$, Maddalena Taras ${ }^{1}$

1) University of Sunderland. United Kingdom

Date of publication: February $15^{\text {th }}, 2016$

Edition period: February 2016-June 2016

To cite this article: Davies, M. S., \& Taras, M. (2016). A comparison of assessment beliefs of science and education lecturers in a University. Multidisciplinary Journal of Educational Research, 6(1), 77-99. doi:10.17583/remie.2016.1766

To link this article: http://dx.doi.org/10.17583/remie.2016.1766

\section{PLEASE SCROLL DOWN FOR ARTICLE}

The terms and conditions of use are related to the Open Journal System and to Creative Commons Attribution License (CC-BY). 


\section{A Comparison of Assessment Beliefs of Science and Education Lecturers in a University}

Mark S. Davies

University of Sunderland
Maddalena Taras

University of Sunderland

\section{Abstract}

Assessment processes and products are important at all levels of education, from the micro context of the classroom to national level. Expertise in assessment is assumed to be a basic attribute of lecturers. However, given the developments of the past 2030 years a panoply of ideals and ideas have permeated discourses so as to camouflage the basics of theoretical understanding. This study examines the beliefs of 50 science and 50 education lecturers at an English university, focusing on data collected via a questionnaire to clarify the beliefs and understanding of assessment terms and the relationship between them. The results demonstrate that there is a great variety of understanding both between and within subject disciplines. This spread, though to be expected in a thinking, developing sector, has implications for learning and teaching and for quality assurance.

Keywords: assessment beliefs, science, education 


\section{Comparación de las Creencias acerca de la Evaluación del Profesorado de Ciencias y de Educación en una Universidad}

Mark S. Davies

University of Sunderland
Maddalena Taras

University of Sunderland

\section{Resumen}

Los procesos y los productos de la evaluación son importantes en todos los niveles educativos, desde el contexto micro del aula hasta el nivel nacional. Se supone que la experiencia en la evaluación es un atributo básico del profesorado. Sin embargo, dada la evolución de los últimos 20-30 años, una panoplia de ideales e ideas han calado en los discursos, con el fin de camuflar los fundamentos de la comprensión teórica. Este estudio examina las creencias de 50 profesores universitarios de ciencias y 50 de profesores universitarios de educación en una universidad inglesa, a partir de los datos recogidos a través de un cuestionario, con el fin de aclarar las creencias y la comprensión de los términos de evaluación y la relación entre ellos. Los resultados demuestran que existe una gran variedad de entendimiento entre y dentro de las materias. Esta expansión, aunque es de esperar en un sector en desarrollo, tiene implicaciones para el aprendizaje y la enseñanza y para la garantía de calidad.

Palabras clave: creencias acerca de la evaluación, ciencia, educación 


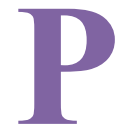

apers published in 2008 (Taras, 2008a), 2013 (Taras \& Davies, 2013) and 2014 (Taras \& Davies, 2014) examined university lecturers' beliefs and opinions relating to assessment in a UK University's departments of education and science to explore their understanding of assessment issues. This paper presents comparison between the two sets of results, to determine the extent to which beliefs are shared across disparate disciplines in a single university. This is important because personal internal coherence is as critical as a shared understanding, given the social nature of communities of practice. In developing strategies to achieve this shared understanding it is important to know where to start, i.e. what the beliefs of staff are and how they differ between disciplines.

Assessment is at the heart of learning and teaching and focuses learners and tutors on the curriculum content, choices and focus of learning. Since learning outcomes are assessed, learning activities within and outside the classroom are ultimately influenced by assessment. How tutors understand assessment processes, functions and products impacts on how they organise their teaching and learning activities and how they envisage the roles learners should play. Learners have, for their part, been required to engage with learning outcomes, criteria and have a pro-active and independent role in learning and assessment. These student responsibilities come with new powers linked to student voice (Taylor \& Robinson, 2009) and this is linked to gauging institutional excellence through, for example, the Course Experience Questionnaire (Australia) and the National Student Survey (UK). It is interesting to note that frequent least positive aspects of students' course experiences are related to assessment and feedback (Yorke, 2013). Thus tutors' perceptions relating to student understanding of assessment are relevant at micro and macro levels.

\section{Background}

The different functions that assessment serves socially and politically, outside of the immediate educational requirements to support validation and accreditation (sometimes known as assessment of learning) and assessment to support learning and understanding (sometimes known as assessment for learning), make it a difficult and contentious subject. Socio-political 


\section{Davies \& Taras - Assessment Beliefs}

tensions vie with the education pressures which already exist. Additional complications arise because the common vocabulary noted above has different contextual and semantic meanings across education sectors, complications which have had limited attention (Black \& Wiliam, 2009; Taras, 2009, 2012a, 2012b; Wiliam, 2009).

In the compulsory sector, the work of Black and Wiliam is recognised as having led discussions on and dissemination of assessment for learning world-wide, beginning with their seminal review article of 1998. In higher education (HE) in the UK, a number of centres of excellence in promoting learning have demonstrated the focus and interests in the discourses of learning, assessing and feedback. Cross-sector links through international journals, conferences and collaborations require a better and clearer understanding of sector-specific differences (Havnes \& McDowell, 2008; Taras, 2008b), particularly in assessment processes, terminologies and protocols.

As regards theory, despite the differences across sectors, much of the literature uses Sadler's (1989) theory of formative assessment as a common baseline. This theory focuses on three aspects: the importance of using feedback to improve work; the necessity of using self-assessment by students in order for the parameters of assessment to be understood and for feedback to be used and therefore to ensure that formative assessment has taken place; and for criteria to be a constant point of discussion as they are in constant flux during assessment.

Another author and his work on assessment is also quoted regularly, Scriven (1967), but in the case of Scriven, the interpretation and reading of his work is not consistent (Taras, 2009; Wiliam, 2007). Taras focuses on the process of assessment and how all assessment uses parameters (that is, criteria, standards, outcomes etc.) either explicitly or implicitly to form a judgement. This judgement is a summation at any given point in time, which if it produces feedback that is used to improve work in learning, becomes formative assessment as stated by Sadler. Wiliam, on the other hand, maintains his focus on functions of assessment and on the irreconcilable separation of summative and formative functions, although in recent work it is no longer the function but the actual use to which the assessment is put that is mooted as important. 
Scriven and Taras appear to be isolated figures who have explicitly considered how summative and formative processes relate. A further consequence of the lack of engagement with the clarification of the relationships between summative and formative assessment functions and processes, and how these relate to feedback, learning, peer and selfassessment, is that the education community is drip-fed disparate discourses which remain segmented and unrelated. Some of the consequences might be that although many pockets of good practice would continue across the education community, and dissemination and take-up of these would help sustain excellence in learning and teaching, disparate understandings of assessments would result in a less coherent picture where pockets of beliefs replace a coherent and complete theoretical picture. Since we are limited by the theoretical frameworks available, if these are limited, flawed and incomplete, this will inevitably be reflected in our understandings.

\section{Research Method}

A questionnaire of 43 questions (Appendix 1) was distributed to 50 lecturers in an Education department at an English university in 2007. The same questionnaire was distributed to a further 50 lecturers in a variety of health and life science-related academic teams in a science faculty at the same university in 2010. For education lecturers the questionnaire was completed during a whole-staff 'awayday', but for the science lecturers it was issued on an opportunistic basis over an eight-month period on occasions when each academic team met to discuss business. All lecturers were told that the questionnaire was to be completed anonymously and were instructed to answer the questions in order and not to go back. They were asked not to confer but told that they could ask for clarification of any question. The questionnaire was not piloted because it was that used by Taras (2008a) who had already undertaken a piloting exercise.

For most questions a yes/no response was required and data were analysed accordingly. However, some questions were qualitative in that they required a written comment. Questions 1 and 3 asked for a rough definition of firstly summative and then formative assessment; questions 2 and 4 asked for examples of summative and formative tasks, respectively; 


\section{Davies \& Taras - Assessment Beliefs}

question 15 asked how formative work is related to summative work; and the final questions, 42 and 43, asked again for definitions of summative and formative assessment. These questions required analysis and interpretation. Key words were selected and analysed to find the general trends that appeared from repetition of words and ideas and the responses were classified.

\section{Results and Discussion}

For all tables numbers are percentage of respondents; Ed = education lecturers; $\mathrm{Sc}=$ science lecturers.

\section{First and Second Definitions of Summative Assessment}

Semantic analysis revealed that in general lecturers were consistent between the first and second definitions of summative assessment (SA), suggesting that completing the questionnaire had no impact on their understandings.

Many more education lecturers linked SA to the concept of final than did science lecturers, though a similar proportion used the idea of grade (Table 1). In the literature, both grade and final are often interlinked (Hargreaves 2005, Taras 2008b). No education lecturer fundamentally misunderstood the concept of SA, but $16 \%$ of science lecturers did, using terms linked to formative assessment (FA).

Table 1

Semantic focus of summative assessment definitions (first and second definitions combined)

Ed Sc

\begin{tabular}{lcc}
\hline 'grade' & 36 & 46 \\
'final' & 80 & 42
\end{tabular}


REMIE-Multidisciplinary Journal of Educational Research, 6(1) 83

\section{First and Second Definitions of Formative Assessment}

Again semantic analysis revealed that in general lecturers were consistent between the first and second definitions of FA, suggesting minimal impact of the questionnaire on their understandings.

Responses mentioning the notion of feedback were low for both education and science lecturers (Table 2). Education lecturers are required to be familiar with the literature to support trainee teachers, and despite feedback being the central component of the accepted definition of FA (Black \& Wiliam 2009; Sadler, 1989; Taras, 2009), it is surprising that so few referred to feedback. Nonetheless we were also surprised by how few science lecturers, as professionals in higher education, referred to feedback.

Table 2

Semantic focus of formative assessment definitions (first and second definitions combined)

\begin{tabular}{lll} 
& Ed & Sc \\
\hline 'feedback' & 28 & 34 \\
\hline
\end{tabular}

\section{Examples of a Summative Assessment Task}

By far the most common response referred to examinations, though education lecturers used this term much more than the science lecturers (Table 3). This may relate to a broader range of assessment tools deployed in the sciences. The proportion of education lecturers using an examination example matches closely the proportion who used the concept of 'final' in the definition, though fewer science lecturers used final in the definition than used exam in the example (Table 1). 
Table 3

Semantic focus of summative assessment task example

\begin{tabular}{lll} 
& Ed & Sc \\
\hline 'examination' & 86 & 52 \\
\hline
\end{tabular}

\section{Examples of a Formative Assessment Task}

$38 \%$ of education lecturers gave examples that focused on classroom processes, presumably aware of the discourse of the compulsory sector which links FA to classroom processes (Black et al, 2003; Black \& Wiliam 2006; Wiliam, 2009). However, $20 \%$ focused on the product of assessment, as did $50 \%$ of science lecturers who used the terms "essay", "presentation", "multiple-choice questionnaire", "coursework", "practice" and "draft", usually associated with FA in the literature, although technically the first four are also examples of SA tasks (Stobart, 2008; Wiliam, 2007, 2009).

$22 \%$ of science lecturers mentioned feedback, though this is not an assessment task, but is information. 16\% mentioned "exam" or "timeconstrained test", both of which are normally associated with SA. Therefore, $38 \%$ of replies from science lecturers would seem inappropriate to the question. Surprisingly $42 \%$ of education lecturers also gave inappropriate non-task related examples.

\section{Formative Assessment Tasks used with Students}

All education lecturers used FA tasks, as did almost all science lecturers (Table 4). Although both groups used FA tasks both in class and for homework, slightly more science lecturers used them in class and slightly more education lecturers for homework. However, it is clear that FA tasks are more associated with classroom work than with homework, given that a significant proportion of both groups indicated that they did not use FA 
tasks for homework (Table 4). This accords with the assessment for learning literature, which focuses on formative assessments as classroom activities (Gardner, 2006; Stobart, 2008). Since the respondents' definitions and understandings of FA tasks are disparate it is difficult to understand what the data on the use of FA with students actually mean. It may be that lecturers want to help learners, but are not clear on why their activities help students.

Most of the assessment for learning literature (particularly, but not exclusively, from the compulsory sector) emphasises the desired separation of SA and FA functions (Black et al, 2003; Black \& Wiliam, 2009; Gardner, 2006; Havnes \& McDowell, 2008; Stobart, 2008; Wiliam, 2007). Since it is evident from the data from both education and science lecturers that it is extremely difficult to separate functions from general understandings of SA and FA it is surprising that education lecturers are less inclined to separate SA and FA than are science lecturers (Table 4). We would have expected education lecturers to be influenced by the literature, which indirectly implies separation because of external examinations in the compulsory sector. Conflation has the advantage of using the focus and work put into SA tasks to provide feedback that can support learning and also be used for other assessments. Separating SA and FA results in repetition and duplication of effort (Taras, 2009).

Table 4.

Formative assessment tasks used with students

\begin{tabular}{llrllllllll}
\hline Response & $\begin{array}{l}\text { 5. FA tasks } \\
\text { used }\end{array}$ & 6. In class & $\begin{array}{l}\text { 7. For } \\
\text { homework }\end{array}$ & $\begin{array}{l}\text { 8. FA and } \\
\text { SA separate }\end{array}$ & $\begin{array}{l}\text { 9. FA and } \\
\text { SA } \\
\text { conflated }\end{array}$ \\
& Ed & Sc & Ed & Sc & Ed & Sc & Ed & Sc & Ed & Sc \\
& & & & & & & & & & \\
\hline Yes & 100 & 94 & 86 & 92 & 78 & 62 & 38 & 48 & 54 & 38 \\
No & & 6 & 10 & 8 & 20 & 34 & 46 & 34 & 38 & 52 \\
Sometimes & & & & & & & 10 & 12 & 6 & 2 \\
\hline
\end{tabular}

Note. Numbers in first row refer to question numbers; where percentages do not sum to 100 this indicates some respondents did not answer the question or gave an ambiguous answer 


\section{Information Given to Students on Formative Assessment Tasks}

$78 \%$ of science lecturers inform students that the task is FA and almost all of those explain how it is formative $(74 \%)$. More lecturers mark the work $(66 \%)$ than grade it (48\%), and most thought that FA is related to SA $(70 \%)$ (Table 5). The figures for education lecturers are comparable if slightly lower: $70 \%$ of lecturers inform students that the task is FA and $64 \%$ explain how it is formative. This is surprising since it could be expected that educationalists are more careful about clarifying pedagogic process to their students. The number of education lecturers marking the work is comparable $(70 \%)$ but far fewer grade it $(30 \%)$ and most of it is related to the summative assessment work $(78 \%)$.

The differences between education and science lecturers again refers to the literature on assessment which distinguishes between SA and FA with the latter sometimes excluded from grading (Black et al, 2003) and sometimes not. When grading does not take place it does not support the understanding of standards against pre-determined criteria (Sadler, 1989, 1998, 2010; Scriven, 1967).

Table 5

Information given to students on formative assessment tasks

\begin{tabular}{|c|c|c|c|c|c|c|c|c|c|c|}
\hline \multirow[t]{2}{*}{ Response } & \multicolumn{2}{|c|}{$\begin{array}{l}11 . \text { Tell } \\
\text { students } \\
\text { task is } \\
\text { FA }\end{array}$} & \multicolumn{2}{|c|}{$\begin{array}{l}12 . \\
\text { Explain } \\
\text { how } \\
\text { task is FA }\end{array}$} & \multicolumn{2}{|c|}{$\begin{array}{l}\text { 13. Is } \\
\text { formative } \\
\text { work marked? }\end{array}$} & \multicolumn{2}{|c|}{$\begin{array}{l}14 . \text { Is } \\
\text { formative } \\
\text { work } \\
\text { graded? }\end{array}$} & \multicolumn{2}{|c|}{$\begin{array}{l}15 . \text { Is } \\
\text { formative } \\
\text { work related } \\
\text { to summative } \\
\text { work? }\end{array}$} \\
\hline & $\mathrm{Ed}$ & Sc & Ed & $\mathrm{Sc}$ & Ed & $\mathrm{Sc}$ & $\mathrm{Ed}$ & Sc & $\mathrm{Ed}$ & $\mathrm{Sc}$ \\
\hline Yes & 70 & 78 & 64 & 74 & 70 & 66 & 30 & 48 & 78 & 70 \\
\hline No & 30 & 18 & 36 & 22 & 24 & 32 & 58 & 48 & 10 & 18 \\
\hline Sometimes & & 2 & & & 6 & & 8 & 2 & 8 & 8 \\
\hline
\end{tabular}


REMIE -Multidisciplinary Journal of Educational Research, 6(1) 87

\section{How is Formative Work Related to Summative Work?}

The research literature is divided on the relationship between SA and FA as noted in the 'Background' section, with some definitions being based on the processes of assessment (Sadler, 1989; Scriven, 1967; Taras 2005, 2009) and some based on the functions of assessment (Black et al, 2003; Black \& Wiliam, 2009; Wiliam, 2007, 2009). It is little wonder therefore that science lecturers were confused about the relationship between SA and FA. Here 32 $\%$ of science lecturers gave responses that followed the framework of the relationship between SA and FA as defined according to the functions of assessment, that is, that FA leads to SA. $76 \%$ of the education lecturers aligned themselves to this view, reinforcing the notion that educationalists' understanding is informed by research into the compulsory sector.

\section{Information on Student Self-assessment}

More education staff use self-assessment, and more believe it is related to FA than do science staff (Table 6).

Similar numbers of education staff present it as SA and believe it can be both, but more science staff believe it can be both than present it as SA. The literature in general associates self-assessment with FA (Black et al, 2003, Black \& Wiliam, 2009; Wiliam, 2007, 2009) because the assumption is made that students will improve their thinking and their work, though more recently FA also requires the explicit use of feedback to become FA (Black \& Wiliam, 2009; Wiliam, 2007, 2009). However, logically there must come a point where even after self-assessment students are not aware of how they can improve their work, and so technically it could be classified as SA. 
88 Davies \& Taras - Assessment Beliefs

Table 6

Information on student self-assessment (ssa)

\begin{tabular}{|c|c|c|c|c|c|c|c|c|}
\hline \multirow[t]{2}{*}{ Response } & \multicolumn{2}{|c|}{$\begin{array}{l}\text { 17. Do students } \\
\text { do ssa? }\end{array}$} & \multicolumn{2}{|c|}{$\begin{array}{l}\text { 18. Do you } \\
\text { present ssa as a } \\
\text { formative } \\
\text { exercise?* }\end{array}$} & \multicolumn{2}{|c|}{$\begin{array}{l}\text { 19. Do you } \\
\text { present ssa } \\
\text { as a } \\
\text { summative } \\
\text { exercise?* }\end{array}$} & \multicolumn{2}{|c|}{$\begin{array}{l}\text { 20. Does ssa } \\
\text { use both SA } \\
\text { and FA? }\end{array}$} \\
\hline & Ed & $\mathrm{Sc}$ & Ed & $\mathrm{Sc}$ & $\mathrm{Ed}$ & $\mathrm{Sc}$ & Ed & $\mathrm{Sc}$ \\
\hline Yes & 70 & 56 & 58 & 46 & 28 & 20 & 30 & 34 \\
\hline No & 28 & 44 & 36 & 50 & 60 & 72 & 66 & 50 \\
\hline Sometimes & 2 & & 4 & & 4 & 2 & 2 & \\
\hline
\end{tabular}

\section{Is Theory Important to us as Teachers?}

Although an overwhelming majority of science lecturers (90\%), though slightly less than education lecturers (96\%), agreed that theory was important, the answers to many of the other questions indicate that the importance is not consistently translated into an understanding of theory or indeed into practical use. While recognising the importance of theory, the scientists might regard it as unimportant to their activities as lecturers and that it is something that does not concern them, perhaps the preserve of educationalists.

\section{Summative and Formative Assessment can be Used for End- or Mid- Course Grades}

Almost all lecturers, especially those in education, agreed that SA can be used for end-course grades and most thought it could be used for midcourse grades (Table 7). However, a significant proportion of both groups did not agree with these positions, and these beliefs appear counter-intuitive because at any point in any assessment process one can stop and provide a summative judgement (Scriven, 1967), and grading may or may not take place at this point. 
More education lecturers than science lecturers thought FA could be used for both end-course and mid-course grades, but the lowest proportion recorded was $40 \%$ (Table 7). Thus there seems a discontinuity in the representation of the relationship between FA and grading in both groups, and this may be interpreted as a general lack of clarity of the terms used. Nearly half of both groups indicated that FA cannot be used for end-course grades (Table 7), and this has implication for both lifelong learning and for progression from one level to another. A significant proportion of respondents from both groups indicated that SA cannot be used for midcourse grades, when this is common practice. Even more indicated that FA cannot be used for mid-course grades.

Table 7

Summative and formative assessment can be used for end-or mid-course grades

\begin{tabular}{|c|c|c|c|c|c|c|c|c|}
\hline \multirow[t]{2}{*}{ Response } & \multicolumn{2}{|c|}{$\begin{array}{l}\text { 22. SA can be } \\
\text { used for end } \\
\text { of course } \\
\text { grades }\end{array}$} & \multicolumn{2}{|c|}{$\begin{array}{l}\text { 23. FA can be } \\
\text { used for end } \\
\text { of course } \\
\text { grades }\end{array}$} & \multicolumn{2}{|c|}{$\begin{array}{l}\text { 24. SA can be } \\
\text { used for } \\
\text { mid-course } \\
\text { grades }\end{array}$} & \multicolumn{2}{|c|}{$\begin{array}{l}\text { 25. FA can be } \\
\text { used for mid- } \\
\text { course grades }\end{array}$} \\
\hline & Ed & $\mathrm{Sc}$ & Ed & $\mathrm{Sc}$ & Ed & $\mathrm{Sc}$ & Ed & $\mathrm{Sc}$ \\
\hline Yes & 98 & 82 & 56 & 40 & 76 & 70 & 66 & 54 \\
\hline No & 2 & 16 & 40 & 54 & 20 & 26 & 32 & 44 \\
\hline Sometimes & & & & 4 & & 2 & & \\
\hline
\end{tabular}

\section{Summative and Formative Assessment Assess Product and/or Process}

SA is seen as a final, product-based activity and FA as assessing a process, both more so by education lecturers (Table 8). However, high numbers of both groups also saw SA as a process and FA as a product: thus, over half recognised a dual function. It is surprising that $30 \%$ of education lecturers do not think that SA assesses process since teaching practice assessment is one of the mainstays of all education programmes. Similarly $32 \%$ of science lecturers agree with this position, even though practical exercises are a common feature of their work. These interpretations were unexpected 
90 Davies \& Taras - Assessment Beliefs

because any assessment (SA, FA, peer- or self-assessment) can be either of product or process or both (Taras, 2005, 2009, 2012b).

Table 8

Summative and formative assessment assess product and/or process

\begin{tabular}{lllll}
\hline Response & $\begin{array}{l}\text { 26. SA assesses } \\
\text { product }\end{array}$ & $\begin{array}{l}\text { 27. SA assesses } \\
\text { process }\end{array}$ & $\begin{array}{l}\text { 28. FA assesses } \\
\text { product }\end{array}$ & $\begin{array}{l}\text { 29. FA assesses } \\
\text { process }\end{array}$
\end{tabular}

\begin{tabular}{lrrrrrrrr} 
& Ed & Sc & Ed & Sc & Ed & Sc & Ed & Sc \\
\hline Yes & 90 & 76 & 58 & 62 & 70 & 66 & 86 & 80 \\
No & 0 & 20 & 30 & 32 & 14 & 28 & 10 & 16 \\
Sometimes & 6 & & 6 & & 6 & 2 & 4 & 2 \\
\hline
\end{tabular}

\section{Summative and Formative Assessment Assess for Validation (Grading) or for Learning}

There was general agreement between the two groups of staff (Table 9). Both SA and FA are seen as promoting learning relevant to grading. Those who did not see FA as requiring grading (40\% in each group) may believe that feedback to students does not occur (Taras, 2008a). This interpretation may not have been realised by respondents, particularly as so few of them explicitly linked the definition of FA with feedback in the definitions. There does not appear to be a clear, single understanding of how SA and FA functions interrelate.

An overwhelming majority (90\% in each group) indicated that FA assesses for learning. The only difference between the two groups was that many more education lecturers thought SA assesses for grading and many more science lecturers $(30 \%)$ thought that SA does not assess for grading, which seems counterintuitive. 
REMIE-Multidisciplinary Journal of Educational Research, 6(1) 91

Table 9

Summative and formative assessment assess for validation (grading) or for learning

\begin{tabular}{lcccccccc}
\hline Response & $\begin{array}{l}\text { 30. SA assesses } \\
\text { for validation }\end{array}$ & \multicolumn{2}{l}{$\begin{array}{l}\text { 31. SA assesses } \\
\text { for learning }\end{array}$} & \multicolumn{2}{l}{$\begin{array}{l}\text { 32. FA assesses } \\
\text { for validation }\end{array}$} & $\begin{array}{l}\text { 33. FA assesses } \\
\text { for learning }\end{array}$ \\
& Ed & Sc & Ed & Sc & Ed & Sc & Ed & Sc \\
\hline Yes & 84 & 62 & 78 & 78 & 48 & 52 & 90 & 90 \\
No & 4 & 30 & 12 & 18 & 40 & 40 & 0 & 8 \\
Sometimes & 6 & & 6 & & 6 & & 2 & \\
\hline
\end{tabular}

\section{Summative and Formative Assessment Provide Useful Feedback}

A large proportion of both groups regarded SA as providing useful feedback (Table 10), which is anomalous in relation to their previous comments. Higher proportions in both groups regarded FA as providing useful feedback (Table 10), but in each there was a low number of respondents who considered that FA and feedback were not connected. Even though these numbers were low, they were surprising since the literature makes feedback (and increasingly, its use) an integral part of FA (Black \& Wiliam, 2009; Sadler 1989; Scriven, 1967).

Table 10

Summative and formative assessment provide useful feedback

\begin{tabular}{lrrrr}
\hline Response & \multicolumn{2}{l}{$\begin{array}{l}\text { 34. SA provides } \\
\text { useful feedback }\end{array}$} & \multicolumn{2}{l}{$\begin{array}{l}\text { 35. FA provides useful } \\
\text { feedback }\end{array}$} \\
& Ed & Sc & Ed & Sc \\
\hline Yes & 82 & 78 & 96 & 88 \\
No & 12 & 18 & 2 & 8 \\
Sometimes & 6 & 2 & 2 & \\
\hline
\end{tabular}




\section{Summative and Formative Assessment are Different or Similar Processes}

More science lecturers regarded SA and FA assessment as similar processes (64\%) than education lecturers (50\%), and vice versa for regarding them as different processes (50\% versus 68\%, Table 11). This may stem from the perception in education that duplication of assessment is required to obtain both SA and FA (Black et al, 2003; Torrance, 1993). That so many lecturers from both groups regard SA and FA as similar processes (that perhaps cannot be disentangled from each other) may account for the discrepancies in understanding noted above. Lecturers may lack confidence in their understanding of assessment terminology despite its common use in various academic contexts.

Table 11

Summative and formative assessment are different or similar processes

\begin{tabular}{lrrllll}
\hline Response & \multicolumn{3}{l}{$\begin{array}{l}\text { 36. SA and FA are } \\
\text { different processes }\end{array}$} & \multicolumn{4}{l}{$\begin{array}{l}\text { 37. SA and FA are } \\
\text { similar processes }\end{array}$} \\
& Ed & Sc & Ed & Sc & \\
\hline Yes & 68 & 50 & 50 & 64 & \\
No & 22 & 42 & 30 & 30 & \\
Sometimes & 6 & 4 & 12 & 4 & \\
\hline
\end{tabular}

\section{Sure/unsure how Summative and Formative Assessment Relate}

This question perhaps reveals most uncertainty as $32 \%$ of science lecturers and $16 \%$ of education lecturers failed to respond, which perhaps indicates 'not sure', in addition to actual 'not sure' responses of $22 \%$ and $4 \%$, respectively. Only $46 \%$ of science lecturers stated that they were sure how $\mathrm{SA}$ and FA relate to each other, but education lecturers were much more confident $(80 \%)$. 


\section{Students Understand/focus on Summative and Formative Assessment}

$72 \%$ of science lecturers believed students understood SA (but only $50 \%$ for FA) (Table 12). $76 \%$ believed students focused on SA (but only $28 \%$ for FA). $28 \%$ of science lecturers believed that students did not understand SA and this increased to $48 \%$ for FA. It is hard to imagine why staff had not persisted in remedying this, since staff think students are engaging with processes that they are not clear about. However, it may be difficult for staff to do this if they are not certain themselves.

Much lower numbers of education staff thought that students did not understand assessment (10\% for SA and $26 \%$ for FA, Table 12): this is to be expected where the students themselves are expected to understand processes used in education and its study. Both groups of staff perceived greater focus by students on summative assessment and again this could be expected if students do not understand assessment. Most higher education students have graduated from a culture where grades have determined their fate and thus focus on graded assessments (e.g. Black et al., 2003). However, it was surprising that such a large proportion of science lecturers did not think students focused on SA (Table 12).

Table 12

Students understand/focus on summative and formative assessment

\begin{tabular}{lllllrrrr}
\hline Response & $\begin{array}{l}\text { 39. Students } \\
\text { understand SA }\end{array}$ & $\begin{array}{l}\text { 40. Students } \\
\text { understand FA }\end{array}$ & $\begin{array}{l}\text { 41. Students } \\
\text { focus on SA }\end{array}$ & $\begin{array}{l}\text { 42. Students } \\
\text { focus on FA }\end{array}$ \\
& Ed & Sc & Ed & Sc & Ed & Sc & Ed & Sc \\
\hline Yes & 74 & 72 & 60 & 50 & 82 & 76 & 32 & 28 \\
No & 10 & 28 & 26 & 48 & 12 & 22 & 50 & 64 \\
Sometimes & 16 & & 14 & 2 & 2 & 2 & 14 & 4 \\
\hline
\end{tabular}




\section{Conclusion}

Although our sample size is adequate for generalizability, we investigated a single institution, thus diminishing generalizability: cross-institution work would be profitable for this field of research. We relied on the honesty and integrity of the respondents and we do not question these. The contradictory aspects of their responses reflect contradictions in the literature. Questionnaires were not all issued at the same time and this might have impacted on the results.

The understanding of assessment terms and their relationships by both science and education lecturers is far from homogenous. However, in general education lecturers seem more closely aligned with the literature and therefore have a greater shared understanding, although this does not coalesce coherently. For example, given the separation of external examinations from classroom-led assessments in the compulsory sector, it is not surprising that education lecturers see a greater separation between SA and FA: this is evidenced by SA being associated with 'final' (Table 1) and 'examination' (Table 3 and see Table 4). Science lecturers, on the other hand, seem more communicative and proactive in their classes, where $92 \%$ carry out FA in class (Table 4) and where they are better at communicating with students about FA tasks (Table 5).

However, both groups find it equally problematic when it comes to relating FA and SA (Tables 7 - 9) and distinguishing between process and product, and what role they play in the assessment calendar. It is not surprising to see this because most of the literature defines SA and FA in terms of functions (e.g. Black \& Wiliam, 2009; Wiliam, 2009). It is difficult to relate functions to the reality of classroom processes and products of assessment. Perturbing as the foregoing might be, perhaps the most surprising result is how lecturers' understandings of SA and FA are communicated (Table 5). In addition, one would expect as a minimum that lecturers communicate assessment requirements to students and that this would translate into student understanding of assessment in general. Table 12 shows that lecturers are not convinced of this understanding which would leave a deficit in their communication with students. 
We are drawn to the overall conclusion that more work is required in understanding the assessment beliefs of staff, across the higher education discipline landscape, because lack of consistency in personal beliefs and understandings about assessment link directly to practice. Only when this is done can we begin to work towards a shared platform for discussion.

\section{References}

Black, P., \& Wiliam, D. (1998). Assessment and classroom learning. Assessment in Education, 5(1), 7-74. doi:10.1080/0969595980050102

Black, P., Harrison, C., Lee, C., Marshall, B., \& Wiliam, D. (2003). Assessment for learning: Putting it into practice. Maidenhead: Open University Press.

Black, P., \& Wiliam, D. (2006). Developing a theory of formative assessment. In J. Gardner (Ed.), Assessment and learning (pp. 81100). London: Sage.

Black, P., \& Wiliam, D. (2009). Developing the theory of formative assessment. Educational Assessment, Evaluation and Accountability, 21(1), 5-31. doi:10.1007/s11092-008-9068-5

Gardner J. (Ed.) (2006). Assessment and learning. London: Sage. Hargreaves, E. (2005). Assessment for learning? Thinking outside the (black) box. Cambridge Journal of Education 35(2), 213-224. doi:10.1080/03057640500146880

Havnes, A., \& McDowell, L. (Eds.) (2008). Balancing Dilemmas in Assessment and Learning in Contemporary Education. New York/London: Routledge.

Sadler, D. R. (1989). Formative assessment and the design of instructional systems. Instructional Science, 18, 145-165.

doi:10.1007/BF00117714

Sadler, D. R. (1998). Formative Assessment: revisiting the territory. Assessment in Education: Principles, Policy and Practice, 5(1), 7785. doi:10.1080/0969595980050104 
Sadler, D. R. (2010). Beyond feedback: developing student capability in complex appraisal. Assessment and Evaluation in Higher Education, 35(5), 535-550. doi:10.1080/02602930903541015

Scriven, M. (1967). The Methodology of Evaluation. In R. Tyler, R. Gagne $\&$ M. Scriven (Eds), Perspectives on Curriculum Evaluation. AERA Monograph Series - Curriculum Evaluation (pp. 39-83). Chicago: Rand McNally and Co.

Stobart, G. (2008). Testing times: The uses and abuses of assessment. New York/London: Routledge.

Taras, M. (2005). Assessment - summative and formative - some theoretical reflections. British Journal of Educational Studies, 53(3), 466-478. doi:10.1111/j.1467-8527.2005.00307.x

Taras, M. (2008a). Summative and formative assessment: Perceptions and realities. Active Learning in Higher Education, 9(2), 172-192. doi:10.1177/1469787408091655

Taras, M. (2008b). Assessment for learning: sectarian divisions of terminology and concepts. Journal of Further and Higher Education 32(4), 389-397. doi:10.1080/03098770802395892

Taras, M. (2009). Summative assessment: the missing link for formative assessment. Journal of Further and Higher Education, 33(1), 57-69. doi:10.1080/03098770802638671

Taras, M. (2012a). Where is the theory in assessment for learning? Online Educational Research Journal. Retrieved from http://www.oerj.org

Taras, M. (2012b). Assessing assessment theories. Online Educational Research Journal. Retrieved from http://www.oerj.org

Taras, M., \& Davies, M. S. (2013). Perceptions and realities in the functions and processes of assessment. Active Learning in Higher Education, 14, 51-61. doi:10.1177/1469787412467128

Taras, M., \& Davies, M. S. (2014). Perceptions and realities in assessment definitions and uses. International Research in Education, 2, 103117. doi: $10.1177 / 1469787412467128$

Taylor, C., \& Robinson, C. (2009). Student voice: theorising power and participation. Pedagogy, Culture and Society, 17(2), 161-175. doi:10.1080/14681360902934392 
REMIE-Multidisciplinary Journal of Educational Research, 6(1) 97

Torrance, H. (1993). Formative assessment: some theoretical problems and empirical questions. Cambridge Journal of Education, 23, 333-343. doi:10.1080/0305764930230310

Wiliam, D. (2007). Keeping learning on track: classroom assessment and the regulation of learning. In F. K. Lester (Ed.), Second handbook of mathematics teaching and learning (pp. 1053-1058). Greenwich CT: Information Age Publishing.

Wiliam, D. (2009). Assessment for learning: why, what and how. London: Institute of Education, University of London.

Yorke, M. (2013). Surveys of 'the student experience' and the politics of feedback. In S. Merry, M. Price, D. Carless \& M. Taras (Eds.) Reconceptualising Feedback in Higher Education (pp. 6-18). London and New York: Routledge.

Mark S. Davies is Professor of Bioscience at the University of Sunderland, UK.

Maddalena Taras is Senior Lecturer in Education at the University of Sunderland, UK.

Contact Address: Mark Davies, Faculty of Applied Sciences, University of Sunderland, Sunderland, SR1 3SD, UK.

Email: mark.davies@sunderland.ac.uk 


\section{Appendix A}

\section{QUESTIONNAIRE on Summative and Formative Assessment}

Where "YES - NO" or "SURE - NOT SURE" is presented, please circle your choice.

1. Give a rough definition of summative assessment.

2. Give an example of a summative assessment task.

3. Give a rough definition of formative assessment.

4. Give an example of a formative assessment task.

5. Do you use formative assessment tasks with your students? YES -NO

6. Do you use formative assessment tasks in class? YES -- NO

7. Do you use formative assessment tasks for homework? YES -- NO

8. Do you keep summative and formative tasks separate? YES -- NO

9. Do you conflate summative and formative tasks? YES -- NO

\section{If you use formative assessment with your students -}

10. Do you tell them it will be a formative assessment? YES -- NO

11. Do you explain how it will be a formative assessment? YES --NO

12. Is formative work marked? YES -- NO

13. Is formative work graded? YES -- NO

14. Is formative work related to summative work? YES -- NO

15. If yes, how is it related?

16. Do your students carry out self-assessment? YES -- NO

17. Do you present self-assessment as a formative exercise? YES -- NO

18. Do you present self-assessment as a summative exercise? YES -- NO

19. Does self-assessment use both summative and formative assessment? YES -NO

20. Is theory important to us as teachers? YES - NO

21. Summative assessment can be used for end of course grades. YES -- NO

22. Formative assessment can be used for end of course grades. YES -- NO

23. Summative assessment can be used for mid-course grades. YES -NO

24. Formative assessment can be used for mid-course grades. YES-- NO

25. Summative - assesses product. YES -- NO

26. Summative - assesses process. YES -- NO 
27. Formative - assesses product. YES -- NO

28. Formative - assesses process. YES -- NO

29. Summative - assesses for validation. YES -- NO

30. Summative - assesses for learning. YES -- NO

31. Formative - assesses for validation. YES -- NO

32. Formative - assesses for learning. YES -- NO

33. Summative provides useful feedback. YES -- NO

34. Formative provides useful feedback. YES -- NO

35. Summative and formative are different processes. YES -- NO

36. Summative and formative are similar processes. YES -- NO

37. I am SURE -- NOT SURE how summative and formative relate to each other.

38. Students understand summative assessment. YES -- NO

39. Students understand formative assessment. YES -- NO

40. Students focus on summative assessment. YES -- NO

41. Students focus on formative assessment. YES -- NO

42. Without looking back, give a definition of summative assessment.

43. Without looking back, give a definition of formative assessment.

Thank you very much for your time and brain power. 